\title{
The Unprecedented Epidemic of Covid-19 and Movement Control Order (MCO) Enforcement: Impact and Recovery Towards Child Care Services Industry in Malaysia
}

\author{
aAidanazimaAbashah, bCheAzlanTaib \\ ${ }^{a}$ School of Technology Management and Logistic, Universiti Utara Malaysia, \& Faculty of Applied Sciences and Humanity, \\ University Malaysia Perlis \\ ${ }^{\mathrm{b}}$ School of Technology Management and Logistic, Universiti Utara Malaysia.

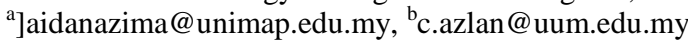

Article History: Received: 10 November 2020; Revised 12 January 2021 Accepted: 27 January 2021; Published online: 5 April 2021

\begin{abstract}
This paper aims to examine the impact of the Covid-19 MCO on child care performance and the recovery strategies to be implemented for post-MCO outbreaks. The quantitative approach is used to investigate the impact of the Covid-19 MCO and to plan recovery strategies based on the questionnaire survey conducted by the child care provider. The paper discusses the provider of child care in Malaysia and shows that Covid-19 Movement Control Order (MCO) affects most child care operations in terms of their cash flow and performance. This study represented only child care providers in Malaysia's northern states who are willing to participate. Consequently, the research suggested that the holistic area in Malaysia should be covered. Extensive research is thus warranted. Child care providers should consider the recovery planning strategy for their business survival due to MCO enforcement. The paper examines the global issues of Covid-19 that lead to a partial lockdown or Movement Control Order (MCO) where the business operation is indirectly adversely affected, especially in the child care industry scenario in Malaysia
\end{abstract}

Index Terms: Movement Control Order (MCO), Partial Lockdown, Covid-19, Child care Service, Industry, Questionnaire

\section{Introduction}

The unprecedented epidemic called Novel Corona Virus or Covid-19 had a devastating effect on most industries during the first quarter of 2020. Today, the same invisible enemy is facing the entire world to fight for. It has become a severe matter for everyone. Covid-19, or the novel coronavirus, was first discovered in Wuhan, China, and is currently spread more quickly to other countries through person to person. Therefore, to break the disease chain, it is necessary to pay extraordinary attention to hygiene, take social distancing, and stay at home during this period. As a result, due to the outbreak of the Covid-19 epidemic, most of the government had implemented a partial lockdown or movement control order (MCO). On March 16, 2020, Malaysia announced its MCO on March 18, 2020, when Malaysia reported about 125 new cases in Malaysia, accounting for the cumulative number of 553 cases [7].

Thus, the Covid-19 epidemic and movement control order (MCO) provided an opportunity to explore its impacts in dealing with the highly uncertain phenomena. In general, the Covid-19 outbreak affects most of those sectors directly. This research paper, therefore, aims at:

-Investigate the effect of Covid-19 during the time of the Movement Control Order (MCO) on the child care industry in particular; and

-Investigate the efficacy of the recovery measures of the "PakejRangsanganEkonomiPrihatin Rakyat" (PRIHATIN) or PRIHATIN Rakyat Economic stimulus Package for the performance of the child care industry.

\section{2, Background}

\section{A. The Situation of Covid 19 MCO}

On March 27, 2020, 130 news cases were reported at the latest press conference of Malaysia's Ministry of Health, with a total of 2,161 cumulative cases. Similarly, unfortunately, three new cases of mortality have been reported and are cumulative, with a total of 26 deaths. However, 259 of them have recovered entirely, which means everybody has paid the effort and commitment to stay at home, particularly the medical officer.

The Novel Corona Virus or Covid-19 pandemic led to MCO being issued by the government for four weeks from March 18 to April 14, 2020, in two different series of announcements. The Lockdown and MCO have taken strict action by other countries worldwide to break the chain of contagious outbreaks. Subsequently, the Enhanced 
Movement Control Order was declared for specific areas in Johor, particularly in the SimpangRenggam high-risk area, where Kluang Johor was in force on March 27 to break the chain disease.

Similarly, the Malaysian Institute of Economic Research's press release on the economic impact of Covid-19 on March 24, 2020, reported that Malaysia's real GDP decreased by about 6.9\% relative to the 2020 baseline, which translates into real GDP growth of $-2.9 \%$ (minus $2.9 \%$ ) in 2020 close to 2019. The country-wide MCO or partial lockdown inevitably leads to economic disruptions affecting the country's production pattern, consumption, and trade in industrial outputs and income and employment [3].

Most industries (manufacturing, food, logistics and transport, tourism, airlines, and small and medium enterprises) are affected by MCO announcements, including the private and government sectors, except for few major and critical industries such as electricity, water, banking, and food production. Therefore, the Malaysian child care industry has also had an immediate impact on MCO enforcement in the fight against the global invisible war disease.

\section{B. Child Care Services in Malaysia}

Referring to the official website of the Department of Social Welfare, the Ministry of Women, Family, and Community Development, the child care center has been identified as any premises where four or more children under the age of four are received from more than one household to be cared for reward based on Section 2, 308 of the Child Care Center 1984. Section 5 Act 308 Classifies that in Malaysia, there are four major categories of children's center, which are the Institution Based Child Care Center (established by a private or non-governmental organization), the Work Place Child Care Center (established for its employees on the premises), the Community Based Child Care Center (receives assistance from the Federal Government or State Government authorities) and the Home-based Child Care Center (located on a registered person's homes under Section 7) [2].

Today, child care is essential and becomes a necessity. It is a trend today when both parents work, and most use child care services. Because of the booms in the child care industry, parents need their services in a big city, such as Kuala Lumpur, Penang Island, and Klang, Selangor. There are four main groups in Malaysia, with different child care fees to support a diverse group of parents. Besides, parents seek their children's best to develop their emotional, intellectual and spiritual, and safety factors.

\section{Child Care Centre Challenges}

Child care business operations rely on the monthly payments they earn from their customers. The primary source for child care providers to operate their businesses is to pay rental fees, workers' wages, utilities, and purchase other essential needs such as maintenance, stationery, grocery, and laundry expenses. It is the most challenging time for child care business providers in this challenging period.

While this is the case during the MCO period, child care is automatically required to stop the operation. At the same time, parents were also directly affected by the MCO announcement when they were also unable to work. Therefore, parents are agreed not to pay the full payment fee as usual, especially for the months of March and April. Similarly, BeritaHarian, Malaysia's newspaper, reported the same issues on April 6, 2020. As a result of parental action not to pay monthly fees, as usual, the child care provider cannot comply with the Employment Act 1955 on the statutory payment by employees of such salary, including the EPF and SOCSO, to each of its employees.

Moreover, the worst situation will continue if the Covid-19 does not settle and the MCO remains much longer than we expected. Besides, Husna Abdul Rahman, President of "PersatuanPengusahaTaska and TadikaPutrajaya" (PUSPAJAYA), confirms that exceptional rentals are being applied to Ministry premises. However, for those in commercial buildings and home premises, monthly fees still need to be paid as usual. At the same time, it also estimates that the majority of child care providers cannot survive if the MCO is continuous. Therefore, on behalf of the child care providers and PUSPAJAYA, she appealed to the government to provide special funds or grants to registered child care providers to ease the burden of Covid-19 MCO while at the same time granting parental subsidies [6].

\section{Recovery Strategy Planning Through the Government Initiatives}

Thus, the announcement by Malaysian Prime Minister, Tan Sri Dato' Haji Muhyiddin Bin Haji MohdYassin, through government initiatives on the 'PakejRangsanganEkonomiPrihatin Rakyat' (PRIHATIN) or PRIHATIN Rakyat Economic Stimulus Package of RM250 billion on March 27, 2020, is of particular benefit to small and medium enterprises (SMEs). There are three main objectives of the incentives: 1) to preserve the welfare of Malaysian society, 2) to encourage business, and 3) to strengthen the development of the economy [5][8][9].

Besides, PRIHATIN is holistic and will benefit everyone when it concerns MCO's direct and indirect impact on each level of society and its size. For this purpose, incentives such as "TabungBantuanKemudahanKhas" or 
"Special Relief Facility for Small Medium Enterprises," "Skim KreditMikro," and "Adjournment or moratorium on loan payments" have been granted to businesses [9]. The RM250 billion package is intended to preserve the welfare of folk, support businesses, including SMEs, and strengthen the economy. Subsequently, to increase their business cash flows, consulting services are provided for employers to apply the suspension of payment, restructuring, and rescheduling of their EPF and SOCSO contributions towards their employees. The expense of income tax installments for three months also applied for SMEs.

Therefore, it is hoped that small and business enterprises, particularly child care, would benefit from the government's initiatives to be sustained during this challenging MCO period.

\section{Study Design}

\section{A. Research Questions and Hypothesis}

This study aims to address two key research questions. The first question is as follows:

RQ1. What impact does the Covid-19 Movement Control Order (MCO) have on the child care business's performance?

The research assumes that, during the MCO period, the child care businesses' challenge period is more likely to face a difficult situation. Moreover, the problem is more likely for business players and for their customers, who are children's parents, who have also been unable to work and are indirectly unable to pay child care fees as usual. Therefore:

H1. There is a significant impact of the Covid-19 Movement Control Order (MCO) on childcare businesses' performance.

Besides, the second research question is as follows:

$R Q 2$. Does the recovery strategy planning of "PakejRangsanganEkonomiPrihatin Rakyat" (PRIHATIN) or PRIHATIN Rakyat Economic Stimulus Package significantly help the child care business performance?

For the second research question, the research assumes that the government initiatives to plan the recovery strategy of 'PakejRangsanganEkonomiPrihatin Rakyat' (PRIHATIN) or the PRIHATIN Rakyat Economic Stimulus Package will help business players, especially in child care, to recover the economic impact of the Covid-19 Movement Control Order (MCO) on their business performance. Therefore:

H2. There is a significant relationship between the recovery strategy planning of "PakejRangsanganEkonomiPrihatin Rakyat" (PRIHATIN) or PRIHATIN Rakyat Economic Stimulus Package and the business performance of the child care business.

Thus, the research framework as follows:

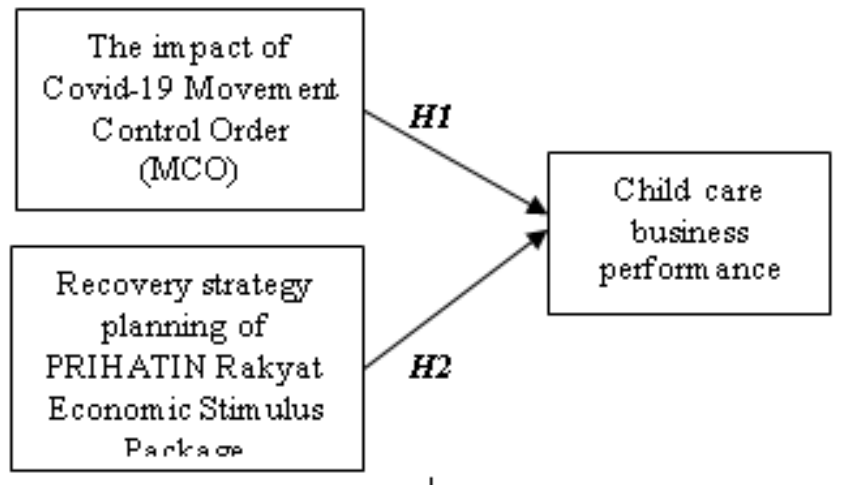

Figure 1: The Research Framework

\section{Methodology}

This paper seeks to provide practical and strategic guidance to child care providers to reduce MCO and Covid19 disease's negative impacts, where the result was derived from the primary data analysis and quantitative approach. Besides, a questionnaire with 27 questions was designed to explore the following areas: the profile of the respondents (6); the impact of Covid-19 MCO on child care performance (8); recovery strategies planning to be implemented on MCO outbreak (7); and child care business performance (6). 
The first part of the survey, which used nominal measurement, included six questions on respondents' demographic profiles. The second part of the survey on the impact of Covid-19 during the MCO consists of eight questions followed by the third part with seven questions and the fourth part with six questions used to measure the impact of Covid-19 MCO, the recovery strategies to be implemented for post-MCO outbreaks and the performance of child care. The respondents were asked to respond using a five-point Likert scale where $1=$ strongly disagree; $2=$ disagree; $3=$ neutral; $4=$ agree; and 5=strongly agree.

The climate and landscape of the survey changed dramatically at the beginning of the 21 st century. Advances in technology and changes in coverage for various survey modes have contributed to an environment where many surveys are now conducted in whole or in part through self-administered web questionnaires [1]. According to the complexities of the MCO period for the researcher to face and meet prospective respondents, a web-based questionnaire called Google Forms had been used. An introductory letter containing a link to a web-based questionnaire, Google Forms, was sent to 100 child care centers in the Northern States, Malaysia, for two weeks in April 2020. The analysis unit is a child care business entity. Specifically, the link was applied to possible respondents who had a child care owner or the department head's management role in the child care center. Multilanguage, Malay, and English were used to ensure that the respondents understood and answered the questions asked. Of the 100 connections in Google Forms, potential respondents were found via WhatsApp and Facebook Messenger. A total of 36 completed questionnaires were issued. The actual response rate was 36\% (36/100).

\section{Finding And Data Analysis}

\section{A. Reliability Analysis}

Reliability is used to test the consistency, validity, and reliability of the products used by a research instrument to calculate the research variables used. The item analysis showed that variables ranged from 0.864 to 0.943 for the reliability or Cronbach's Alpha value (see Table 1).

Table 1: Reliability Analysis

\begin{tabular}{|c|c|c|c|}
\hline \multirow{2}{*}{ Variable } & \multirow[b]{2}{*}{ Item } & \multirow{2}{*}{$\begin{array}{l}\quad \mathrm{N} \\
\text { o. of } \\
\text { Item }\end{array}$} & \multirow{2}{*}{\begin{tabular}{l}
\multicolumn{2}{c}{ Cronbach } \\
Alpha \& \\
Remarks
\end{tabular}} \\
\hline & & & \\
\hline \multirow{8}{*}{$\begin{array}{l}\text { Impact } \\
\text { Covid-19 MCO }\end{array}$} & $\begin{array}{l}\text { IM1. Covid } 19 \text { Movement Control Order (MCO) will } \\
\text { have an impact on the economy }\end{array}$ & \multirow{8}{*}{8} & \multirow{8}{*}{$\begin{array}{l}0.943 \\
\text { (Excellent) }\end{array}$} \\
\hline & $\begin{array}{l}\text { IM2. Covid } 19 \text { Movement Control Order (MCO) will } \\
\text { have an impact on the childcare industry }\end{array}$ & & \\
\hline & $\begin{array}{l}\text { IM3. Covid } 19 \text { Movement Control Order (MCO) will } \\
\text { have an impact on parents' willingness to pay a fee }\end{array}$ & & \\
\hline & $\begin{array}{l}\text { IM4. Covid } 19 \text { Movement Control Order (MCO) will } \\
\text { have an impact on paying staff salary. }\end{array}$ & & \\
\hline & $\begin{array}{l}\text { IM5. Covid } 19 \text { Movement Control Order (MCO) will } \\
\text { have an impact on paying staff EPF and SOCSO. }\end{array}$ & & \\
\hline & $\begin{array}{l}\text { IM6. Covid } 19 \text { Movement Control Order (MCO) will } \\
\text { have an impact on paying utility bills (rental, electric, } \\
\text { water, Astro, telephone, and internet) }\end{array}$ & & \\
\hline & $\begin{array}{l}\text { IM7. Covid } 19 \text { Movement Control Order (MCO) will } \\
\text { have an impact on paying a business loan }\end{array}$ & & \\
\hline & $\begin{array}{l}\text { IM8. Covid } 19 \text { Movement Control Order (MCO) has } \\
\text { led to customers decision to stop the childcare services }\end{array}$ & & \\
\hline $\begin{array}{l}\text { Recovery } \\
\text { Strategies Planning }\end{array}$ & $\begin{array}{l}\text { S1. During the movement restrictions period, I have } \\
\text { utilized this time by planning my childcare center's future } \\
\text { aims and goals. }\end{array}$ & \multirow{2}{*}{7} & \multirow{2}{*}{$\begin{array}{l}0.864 \\
\text { (Good) }\end{array}$} \\
\hline $\begin{array}{l}\text { on Post-MCO } \\
\text { Outbreak }\end{array}$ & $\begin{array}{l}\text { S2. During the movement restrictions period, I have } \\
\text { utilized this time by planning my childcare center future } \\
\text { planning. }\end{array}$ & & \\
\hline
\end{tabular}




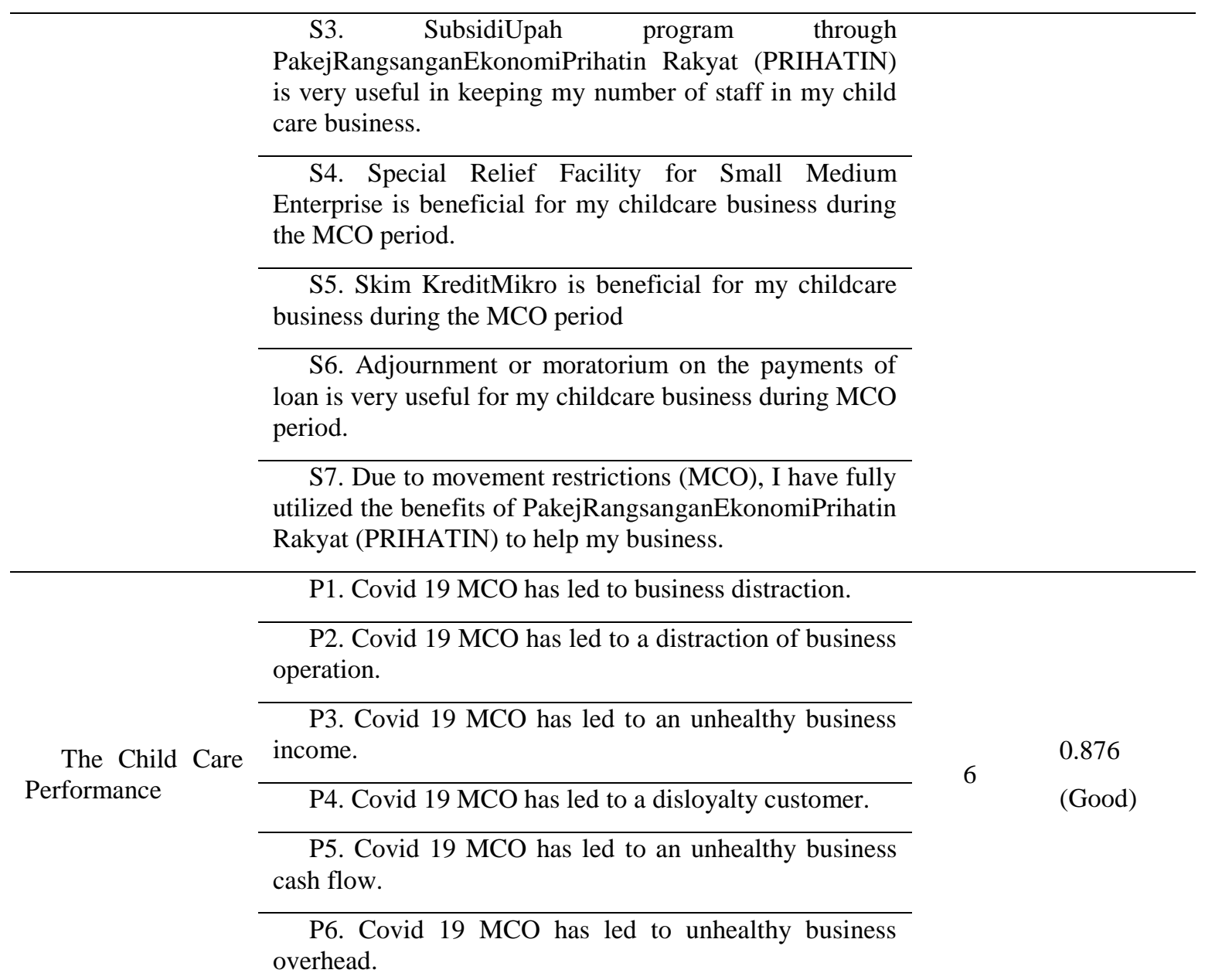

The $\alpha$-value of the dependent variable-child care output was 0.876 , and the $\alpha$-value of the independent variables was 0.943 and 0.864, respectively, for the effects of Covid-19 MCO and Recovery Strategies Planning on Post-MCO outbreaks. Therefore, all variables are considered excellent or very good due to their Cronbach alpha value, which is more than 0.8 .

\section{B. Respondent Profile}

This section provides an overview of the respondent's demographic profile and their background where the analysis unit is the child care business center.

Table 2: Respondent Profile

\begin{tabular}{|c|c|c|c|}
\hline \multirow{2}{*}{ Items } & & Freque & Per \\
\hline & & ncy & cent \\
\hline \multirow[t]{3}{*}{ D1. State } & Perlis & 24 & 766. \\
\hline & Kedah & 12 & 33. \\
\hline & Total & 36 & 100 \\
\hline \multirow[t]{3}{*}{$\begin{array}{l}\text { D2. Child care } \\
\text { Status }\end{array}$} & $\begin{array}{l}\text { Institution-Based Child Care } \\
\text { Centre }\end{array}$ & 24 & 766. \\
\hline & $\begin{array}{l}\text { Community-Based Child Care } \\
\text { Centre }\end{array}$ & 9 & $0^{25 .}$ \\
\hline & Home-Based Child-Care Centre & 3 & 8.3 \\
\hline
\end{tabular}




\begin{tabular}{|c|c|c|c|}
\hline & Total & 36 & 100 \\
\hline \multirow[t]{8}{*}{$\begin{array}{l}\text { D3. Number of } \\
\text { Kids }\end{array}$} & $4-6$ & 6 & 716. \\
\hline & $7-9$ & 6 & $7^{16 .}$ \\
\hline & $13-15$ & 3 & 8.3 \\
\hline & $16-18$ & 6 & $7{ }^{16 .}$ \\
\hline & $19-21$ & 6 & $7{ }^{16 .}$ \\
\hline & $22-24$ & 6 & $7^{16 .}$ \\
\hline & 25 and above & 3 & 8.3 \\
\hline & Total & 36 & 100 \\
\hline \multirow[t]{4}{*}{$\begin{array}{l}\text { D4. Number of } \\
\text { Staff }\end{array}$} & 1 only & 6 & 716. \\
\hline & $2-4$ & 24 & 766. \\
\hline & $8-10$ & 6 & $7{ }^{16 .}$ \\
\hline & Total & 36 & 100 \\
\hline \multirow[t]{4}{*}{$\begin{array}{l}\text { D5. } \\
\text { Status }\end{array}$} & Rental & 24 & 766. \\
\hline & Aid by Government & 6 & 716. \\
\hline & Home & 6 & $7{ }^{16 .}$ \\
\hline & Total & 36 & 100 \\
\hline \multirow[t]{5}{*}{$\begin{array}{r}\text { D6. } \\
\text { Period }\end{array}$} & Less than 1 Year & 6 & 716. \\
\hline & $1-3$ years & 3 & 8.3 \\
\hline & $4-6$ years & 18 & $0^{50 .}$ \\
\hline & 7 years and above & 9 & $0^{25 .}$ \\
\hline & Total & 36 & 100 \\
\hline
\end{tabular}

The respondents to child care accounted for slightly more than half of the total number of 24 respondents (66.7\%) compared to those of Kedah 22 (33.3\%). More than half or 24 (66.7\%) of the respondents are from the Institution-Based Child Care Center, 25\% are from the Community-Based Child Care Center, and $8.3 \%$ are from the Home-Based Child Care Center.

The number of children in the surveyed child care center was $16.7 \%$ for 4 to 6 children, 7 to 9 children, 16 to 18 children, 19 to 21 children, and 22 to 24 children. Besides, $8.3 \%$ are between 13 and 15 children and more than 25 children, respectively. Simultaneously, for the capacity of the number of staff, more than half of $66.7 \%$ of child care staff employed between 2 and 4 in their child care center, and the remaining $16.7 \%$ hired only one staff and between 8 and 10 staff respectively. 
As far as the premises that they operated their child care centers are concerned, most of them are rent, and the remaining $16.7 \%$ are government and home-based aid. Up to $50 \%$ of child care was operated for 4 to 6 years, followed by $25 \%$ for more than seven years, $16.7 \%$ for less than one year, and $8.3 \%$ for 1 to 3 years.

\section{Descriptive Analysis}

Table 3 below lists all variables' mean values at high score and range from 4.30 to 4.448 . The impact of the Covid-19 MCO determinant scored the highest mean of 4.448, followed by Recovery Strategies Planning for PostMCO Outbreak at 4.321, and Child Care Performance at 4.30 mean score.

In the meantime, the standard deviation for all variables varies from 0.587 to 0.874 . Child Care Performance was the lowest standard deviation value, and the highest was Covid-19 MCO's impact.

Table 3: Descriptive Analysis

\begin{tabular}{|c|c|c|c|}
\hline Variables & & $\operatorname{lan}_{\text {ean }}^{\mathrm{M}}$ & $\begin{array}{l}\text { Standard } \\
\text { Deviation }\end{array}$ \\
\hline Impact of Covid-19 MCO & 6 & $\begin{array}{r}4 . \\
448\end{array}$ & 0.874 \\
\hline $\begin{array}{l}\text { Recovery Strategies Planning on Post-MCO } \\
\text { Outbreak }\end{array}$ & 6 & 421 & 0.634 \\
\hline The Child Care Performance & 6 & $30^{4 .}$ & 0.587 \\
\hline
\end{tabular}

\section{Pearson Correlation Analysis}

Pearson correlation analysis was used to calculate the p-value between The Child Care Performance as a dependent variable and the two independent variables: The Covid-19 MCO Effect and Post-MCO Outbreak Recovery Strategy Planning.

Table 4: Correlation Analysis

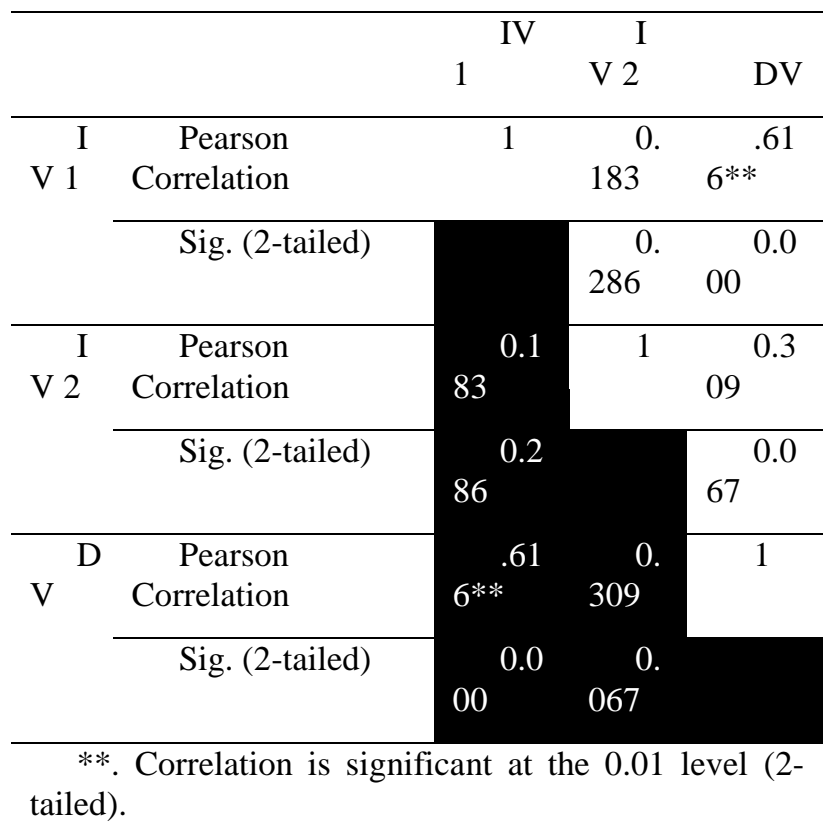

Table 4 showed a positive relationship between The Child Care Performance and Impact of Covid-19 MCO $(r=0.616, p<0.05)$ and Recovery Strategies Planning on Post-MCO Outbreak $(r=0.309, p>0.05)$.

\section{E. Regression Analysis}

Table 5 shows that R's value is 0.647 , thereby indicating a moderate relationship between these variables. The $\mathrm{R}$ square value of 0.419 means that independent variables contributed $41.9 \%$ of The Child Care Performance's total variation. In the meantime, the adjusted $\mathrm{R}$ Square $=0.384$ can be concluded that $38.4 \%$ of the dependent variable's variation is attributed to the independent variables. 
Table 5: Linear Regression on the Independent Variables and Child Care Performance

\begin{tabular}{|c|c|c|c|c|}
\hline \multirow{2}{*}{$\mathrm{del}^{\text {Mo }}$} & \multirow[t]{2}{*}{$\mathrm{R}$} & \multirow{2}{*}{$\begin{array}{c}\mathrm{R} \\
\text { Square }\end{array}$} & Adju & Std. \\
\hline & & & $\begin{array}{l}\text { sted R } \\
\text { Square }\end{array}$ & $\begin{array}{l}\text { Error of the } \\
\text { Estimate }\end{array}$ \\
\hline 1 & .647 & .419 & .384 & 46077. \\
\hline
\end{tabular}

a. Predictors: (Constant), Impact of Covid-19 MCO,
Recovery Strategies Planning on Post-MCO Outbreak

b. Dependent Variable: The Child Care Performance

The outcome of multiple regression analysis shown in Table 6 showed that all independent variables: the effect of Covid-19 MCO has a significant relationship to the dependent variable, Child Care Performance since the relevant $\mathrm{p}$-value is less than 0.05. While the Recovery Strategy Planning on Post-MCO Outbreak indicates pvalue $=0.142$ is not significant where the variables' $\mathrm{p}$-value is greater than 0.05 .

The $\beta$ result indicates a positive relationship for all independent variables. Standardized coefficients $\beta$-value of Impact of Covid-19 MCO is 0.579. Meanwhile, Recovery Strategies Planning on Post-MCO Outbreak shows $\beta$ result of 0.203 .

Table 6: Multiple Regression Analysis

\begin{tabular}{|c|c|c|c|c|}
\hline \multirow{4}{*}{ Model } & Unstandardi & Standardi & \multirow[b]{4}{*}{$\mathrm{T}$} & \multirow[b]{4}{*}{ g. } \\
\hline & zed & zed & & \\
\hline & Coefficients & Coefficients & & \\
\hline & Beta & Beta & & \\
\hline ant) 1 (Const & 1.759 & & $\begin{array}{l}2 . \\
854\end{array}$ & $007^{0 .}$ \\
\hline $\begin{array}{l}\text { Impact } \\
\text { of Covid- } \\
19 \mathrm{MCO}\end{array}$ & 0.388 & 0.579 & $286^{4 .}$ & $000^{0 .}$ \\
\hline $\begin{array}{l}\text { Recover } \\
\text { y Strategies } \\
\text { Planning }\end{array}$ & 0.188 & 0.203 & $505^{1 .}$ & $142^{0 .}$ \\
\hline
\end{tabular}

H1. There is a significant impact on childcare business performance between the Covid-19 Movement Control Order (MCO).

Hypothesis 1 clarified the relation between the Covid-19 Movement Control Order (MCO) impact and the child care business's performance. It shows a highly positive significant relationship at a significant level of 0.01 , with Pearson correlation, $r=0.616$ and $p<0.05$. Furthermore, the regression analysis result in Table 6 shows the positive results for the significant result between these two variables with the Beta value of 0.579 and 0.00 . Both results reveal a significant positive relationship. Hypothesis 1, therefore, constitutes the accepted status.

H2. There is a significant relationship between the recovery strategy planning of the "PakejRangsanganEkonomiPrihatin Rakyat" (PRIHATIN) or PRIHATIN Rakyat Economic Stimulus Package and child care business performance.

Hypothesis 2 explained the relationship between recovery strategy planning of "PakejRangsanganEkonomiPrihatin Rakyat" (PRIHATIN) or PRIHATIN Rakyat Economic Stimulus Package and childcare business performance. The relationship showed a very positive relationship between these two variables with a Beta value of 0.203 and a significant result of 0.142 . In the meantime, based on the results of the Pearson correlation, $\mathrm{r}=0.309$ and $\mathrm{p}$-value are more than 0.05. In particular, Hypothesis 2 is at the rejected status.

Therefore, H1. A significant impact between the Covid-19 Movement Control Order (MCO) towards child care business performance is accepted while and $\mathrm{H} 2$. There is a significant relationship between the recovery 
strategy planning of "PakejRangsanganEkonomiPrihatin Rakyat" (PRIHATIN) orPRIHATIN Rakyat Economic Stimulus Package and child care business performance is rejected.

\section{Discussions And Conclusion}

This study aimed to examine the impact of Covid-19 MCO on child care performance and the planning of recovery strategies to be implemented for the post-MCO outbreak. In other words, the aim was to understand the framework for child care performance by looking at the impact of the Covid-19 MCO and its recovery strategies on child care business providers in Malaysia. The same theme of findings was found in [4], stating that SARS impacted the practical and strategic approach to crisis preparation and management, specifically on Canada's tourism industry.

The analysis done reveals a significant impact on child care performance due to the crisis. Simultaneously, the enforcement of the MCO has led to government initiatives that have also proved to be very excellent initiatives for recovering the business burden in the face of the Covid-19 crisis. As for the first hypothesis, the Covid-19 Movement Control Order (MCO) and child care business performance has a significant impact. Even so, due to MCO enforcement, business providers, in particular, the child care business center, could not operate as usual, so that they would be faced with a lack of income to pay their business commitments, such as rental of premises, payment of utility bills and staff salaries, including EPF and SOCSO contributions. Simultaneously, the worst thing is that the parents are also refused to pay the fees.

Moreover, regarding the second hypothesis, the significant relationship between recovery strategy planning of "PakejRangsanganEkonomiPrihatin Rakyat" (PRIHATIN) or PRIHATIN Rakyat Economic Stimulus Package and child care business performance, the results showed an insignificant relationship. Thus, Hypothesis 2 is rejected. While this is the case, most of the respondents participating in the data collection were from the Institution-Based Child Care Center (66.4\%) and rent the Child Care Center from the landlord or the premises' owner. Hence, the benefits of adjournment or moratorium on loan payment given to business are not received indirectly to the child care providers. Besides, the data were collected during the first PRIHATIN Rakyat Economic Stimulus Package, where there is an improvement on the second PRIHATIN Plus announcement where the Prime Minister encourages the owner of the premises to share the same moratorium benefits with the business tenant.

Getting to grips with a crisis pandemic outbreak such as Covid-19 that led to a Movement Control Order (MCO) or a partial lockdown can be difficult, albeit very necessary, action by business players, particularly for child care providers. The direct and indirect impact includes both strategic and practical actions for the child care industry. Preparation and recovery strategy plan needed to minimize the negative impact of a crisis or disaster. A well-developed plan initiative, taken at the same time by the government, will enable organizations to respond quickly and effectively to the crisis.

Hopefully, if another epidemic crisis like Covid-19 hit Malaysia and other countries again, it is not a question mark. Every country worldwide had learned from this crisis and so far enforced the best recovery planning in dealing with the current and future crises. When it happens, the key is there is no way to avoid it. The only thing everyone can do, the authorities, is to have better planning to minimize the impacts..

\section{References}

Paul C. Beatty, Debbie Collins, Lyn Kaye, Jose-Luis Padilla, Gordon B. Willis \& Amanda Wilmot (2020). Advances in Questionnaire Design, Development, Evaluation, and Testing. First Edition, John Wiley \& Sons Inc.

Official Portal Department of Social Welfare, Ministry of Women, Family and Community Development, available http://www.jkm.gov.my/jkm/index.php?r=portal/left\&id=b0twWGNVR0N2VjdGV2N0S3JkbjlEZz09 (accessed April 1, 2010).

"Malaysian Institute of Economic Research (MIER) (2020). Press Statement the Economic Impact of Covid-19 March 24, 2020", available at https://twitter.com/MIERMalaysia/status/1242427560970997760?ref_src=twsrc\%5Etfw\%7Ctwcamp\%5Eem beddedtimeline $\% 7 C$ twterm\%5Eprofile\%3AInstituteMier\&ref_url=https $\% 3 \mathrm{~A} \% 2 \mathrm{~F} \% 2 \mathrm{Fwww} . \mathrm{mier}$. org.my $\% 2 \mathrm{~F}$ (accessed April 1, 2010).

Paula Johnson Tew, Zhen Lu, George Tolomiczenko\& Joanne Gellatly (2008). "SARS: Lessons in Strategic Planning for Hoteliers and Destination Marketers," International Journal of Contemporary Hospitality Management Vol. 20, No. 3, pp. 332-346

“TeksUcapan YAB Tan Sri Dato' Haji Muhyiddin Bin Haji MohdYassinPerdanaMenteri Malaysia PakejRangsanganEkonomiPrihatin Rakyat (PRIHATIN)”, available at: 
https://www.treasury.gov.my/pdf/Teks-Ucapan-Pakej-Rangsangan-Ekonomi-Prihatin-Rakyat.pdf (accessed 1 April 2010)

PengusahaTaska, TadikaPutrajayaTersepitIbuBapaEnggan Bayar Yuran (2020), available at: https://www.bharian.com.my/berita/nasional/2020/04/673523/pengusaha-taska-tadika-putrajaya-tersepit-ibubapa-enggan-bayar-yuran (accessed 6 April 2020).

KenyataanAkhbarKementerianKesihatan Malaysia SituasiSemasaJangkitanPenyakit Coronavirus 2019 (COVID-
19)
di
Malaysia
$16 \quad$ Mac
2020
(2020),
available
at:

file://C:/Users/ASUS\%20VivoBook/Downloads/Kenyataan\%20Akhbar\%20YBMK\%20COVID19\%20(16\%20Mac\%202020)\%20(1).pdf (accessed 18 Mac 2020).

PakejRangsanganEkonomi PRIHATIN Rakyat, Ministry of Finance Malaysia (2020), available at: https://www.treasury.gov.my/pdf/Infografik-Prihatin.pdf (accessed 9 April 2020).

Speech Text, YAB Tan Sri Dato' Haji Muhyiddin Bin Haji MohdYassin, Prime Minister of Malaysia, Additional PRIHATIN SME Economic Stimulus Package (PRIHATIN) (2020), Prime Minister's Office of Malaysia, available at https://www.pmo.gov.my/2020/04/langkah-tambahan-bagi-pakej-rangsangan-ekonomi-prihatinrakyat-prihatin/ (accessed April 10, 2020). 